\title{
Identifying Genotypic Heterogeneity in 'McFarlin' Cranberry: A Randomly-amplified Polymorphic DNA (RAPD) and Phenotypic Analysis
}

\author{
R.G. Novy ${ }^{1}$ and N. Vorsa ${ }^{2}$ \\ Blueberry and Cranberry Research and Extension Center, Rutgers University Chatsworth, NJ08019, and \\ Department of Plant Science, Rutgers University, New Brunswick, NJ 08903 \\ K. Patten ${ }^{3}$ \\ Washington State University, Long Beach Research and Extension Unit, Route 1, Box 570 Long Beach, \\ WA 98631 \\ Additional index words. Vaccinium macrocarpon, yield, fruit set, pollen, fertility, genotyping, DNA fingerprinting
}

\begin{abstract}
Highly variable productivity among Vaccinium macrocarpon (Ait.) Pursh 'McFarlin' bogs in Washington has been noted by growers. The fruiting habits of 12 Washington 'McFarlin' bogs, ranging from 5.7-28.4 t/ha productivity were characterized. Uprights from each bog were characterized using RAPD markers, and then used in a greenhouse pollination experiment to determine if variation in fruiting and fertility phenotypes could be associated with RAPD profiles. Fifteen RAPD profiles were identified, and genetic heterogeneity was high among the 12 bogs. An association between RAPD profiles and reproduction characteristics was observed. The most frequent $(30 \%)$ RAPD profile appeared to represent the 'true' 'McFarlin', since it was abundant in higher-yielding bogs and its profile was identical to 'McFarlin' samples from other growing regions. A unique RAPD profile was also identified which exhibited high yield characteristics, but did not appear to be related to 'McFarlin'. The Washington 'McFarlin' bogs examined are composed of a diverse array of genotypes with variable fruiting phenotypes, indicating the variability in production has a genetic component.
\end{abstract}

Cultivated cranberry is a North American, woody, perennial species of recent domestication. Cultivation was initiated in the early 1800 s with the selection of native genotypes from Massachusetts, New Jersey, and Wisconsin bogs. Although over 139 clonal cultivars are recognized, the majority of the acreage is still planted with one of four cultivars that were selected from native bogs: 'Early Black', 'Howes', 'McFarlin', and 'Searles' (Eck, 1990).

Of the four major native cultivars, 'McFarlin' is the most widely adapted, being grown in Massachusetts, Wisconsin, and the Pacific Northwest. Selected from a native Massachusetts bog in 1874, 'McFarlin' was introduced into Washington in the $1880 \mathrm{~s}$ and is still considered the predominant cultivar.

Among 'McFarlin' bogs in Washington, highly variable productivity ranging from 5.7-28.4 t/ha has been noted by growers (K. Patten, unpublished data). Variation has been noted for fruit set, fruit size and shape, and pigmentation intensity. These traits are quantitative, and their variability may be due to differences among bog environments. However, the observed variability may have a genetic component. Commercial cranberry plantings, thought to consist of one genotype, can actually be composed of more than one genotype (Novy and Vorsa, 1995). Few qualitative traits are available to facilitate the discrimination of cranberry genotypes.

Cranberry reproduces naturally through both sexual (fruit bearing uprights) and asexual (stolons) modes. Typically, commercial bogs are established clonally through the harvest and planting of

Received for publication 15 June 1995. Accepted for publication 8 Nov. 1995. New Jersey Agricultural Experiment Station publication supported by state funds, Hatch Act, CSRS grant 93-34155-8382, and Ocean Spray Cranberries, Inc. We thank P. Smouse for assistance in statistical analyses and F. Caruso and I. Demoranville for providing 'McFarlin' samples from Mass. The cost of publishing this paper was defrayed in part by the payment of page charges. Under postal regulations, this paper therefore must be hereby marked advertisement solely to indicate this fact.

${ }^{1}$ Postdoctoral associate.

${ }^{2}$ Associate professor. To whom reprint requests should be addressed.

${ }^{3}$ Associate horticulturist. stolons. Once established, cultivar plantings are generally cultivated for long periods of time (the oldest bogs in this study were over 70 years). Because of the longevity of commercial plantings, the opportunity exists for seedlings from fallen fruit and native clones to become established, thereby generating genotypic heterogeneity. Stolons harvested from such a genetically diverse population for new bog establishment or renovations would perpetuate genotypic heterogeneity. Furthermore, depending on how successfully different genotypes establish at new locations, the frequencies of various genotypes could further change with the possibility of a less frequent genotype becoming predominant in a new environment. It may also be hypothesized that genotypes having reduced fertility and reproductive load would be more vegetatively competitive, and be preferentially selected during commercial stolon harvesting. Lower yields might be expected in bogs established with stolons having a preponderance of these vegetatively competitive clones.

The purpose of this study was to determine if the observed variation for productivity in Washington 'McFarlin' bogs could be genetic in origin. In other words, is 'McFarlin' represented by several genotypes varying in productivity rather than being represented by a single genotype (as expected in a clonally propagated cultivar)? The fruiting habits of 12 Washington 'McFarlin' bogs, ranging from 5.7 to $28.4 \mathrm{t} /$ ha in productivity were characterized to determine what components of yield might contribute to the observed variability in bog productivity. Uprights were sampled from each bog for RAPD genotyping. In addition, these uprights were pollinated and a number of reproductive characteristics were evaluated for each RAPD-profiled upright to assess the relationship between genotype and traits that can impact productivity.

\section{Materials and Methods}

Characterization of fruiting habits of 'McFarlin' bogs. In 1993 and 1994, 12 Washington 'McFarlin' bogs (Table 1) ranging from low to high productivity, based on historical observations, were 
Table 1. Origin and description of 'McFarlin' clonal representatives from Washington.

\begin{tabular}{|c|c|c|c|c|}
\hline Bog & Location & $\begin{array}{l}\text { Average } \\
\text { yield t/ha }\end{array}$ & $\begin{array}{l}\text { Date } \\
\text { planted }\end{array}$ & Grower's comments \\
\hline$\overline{1}$ & Grayland & 5.7 & $1930 \mathrm{~s}$ & Flowers well, poor set of firm, small fruit; poor 'McFarlin'. \\
\hline 2 & Grayland & 6.8 & Unknown & $\begin{array}{l}\text { Non-uniform flowering and berry set; small fruit with poor color; } \\
\text { poor 'McFarlin'. }\end{array}$ \\
\hline 3 & Grayland & 22.6 & $1930-1940 \mathrm{~s}$ & Early ripening with large fruit, good 'McFarlin'. \\
\hline 4 & Grayland & 25.5 & 1930 & Good set of large fruit; good 'McFarlin'. \\
\hline 5 & Grayland & 5.7 & 1955 & Flowers well; poor berry set;poor 'McFarlin'. \\
\hline 6 & Grayland & 19.9 & Unknown & Good set of football-shaped berries, good 'McFarlin'. \\
\hline 7 & Grayland & 22.7 & 1927 & Early ripening, large, blue-lustered fruit. \\
\hline 8 & Grayland & 22.7 & 1930 & Weevil damage in certain areas of bog. \\
\hline 9 & Long Beach & 9.1 & $1930 \mathrm{~s}$ & Smaller leaf, stem, and berry size than typical 'McFarlin'. \\
\hline 10 & Long Beach ${ }^{\mathrm{z}}$ & 10.2 & $1960 \mathrm{~s}$ & Research bog with variable yield; generally poor with smaller fruit. \\
\hline 11 & Long Beach & 14.2 & $1940 \mathrm{~s}$ & Mid-maturing 'McFarlin' with medium-sized berries. \\
\hline 12 & Long Beach & 28.4 & $1940 \mathrm{~s}$ & Early- maturing with large berries; good 'McFarlin'. \\
\hline
\end{tabular}

${ }^{\mathrm{Z}}$ Washington State University-Long Beach Research and Extension Unit.

sampled for yield $\left(\mathrm{g} \cdot \mathrm{dm}^{-2}\right)$, berry number $/ \mathrm{dm}^{2}$, seeds/berry $(1993$ only), mean berry weight (g/berry), berry set (percent flowers set), flowers/upright, and berries/upright. For each bog, six samples were taken. Yield and berry number estimates were determined by placing an 18.8 -cm-diameter ring $\left(3.2 \mathrm{dm}^{2}\right)$ on the vines, harvesting all berries within the ring. The fruit sample was weighed and berries counted. Mean berry weight was obtained by dividing yield by berry number. Seed set was determined by counting the seed from five berries from each of the six samples from each bog (30 seed counts). Fruit set, flowers/upright, and berries/upright were determined by sampling 25 uprights from areas immediately adjacent to each of the six yield locations of each bog. The number of flowers and berries were scored for each upright (in cranberry the pedicels of flowers that do not set fruit remain attached). Mean berry set was determined from the total number of berries divided by the total number of flowers on each of the 25 uprights.

ANOVA was performed using SAS, (SAS Inst., Cary, N.C.). Since no preconceived contrasts were employed, mean separation was based on Student-Newman-Keuls test $(P \leq 0.05)$.

Plant material for RAPD analysis and greenhouse fruiting study. In late winter of 1993, 25 uprights (vertical shoots with and without flower buds) were collected from each of the 12 Washington bogs (Table 1). Five uprights were selected from each of five areas within each bog. Uprights were sent to the Blueberry and Cranberry Research and Extension Center, Chatsworth, N.J. Up- rights were rooted in $15.2-\mathrm{cm}$ pots with a 50 sand $/ 50$ peat $(\mathrm{v} / \mathrm{v})$ soil mixture, and maintained in a greenhouse. To induce fruit formation, flowers on uprights were self-pollinated at anthesis using a glass slide as described by Sarracino and Vorsa (1991).

Plant material used in RAPD analyses. In a primary RAPD analysis, four fruiting uprights from each bog were selected at random, except when extremes in berry morphology were observed within samples from the same bog. In such instances these divergent types were included in the study. Of the 48 samples, 45 had DNA that could be successfully amplified by the polymerase chain reaction. Using an informative subset of three primers from the primary analysis, an additional 22 uprights were analyzed with RAPD markers and assigned profiles corresponding to those observed in the primary RAPD analysis.

Included in the primary RAPD analysis were six 'McFarlin' representatives and an 'Early Black' clone previously analyzed with RAPD markers (Table 2) by Novy and Vorsa (1995). The 'Early Black' clone was included because it had a RAPD profile identical to those of two 'McFarlin' clones from the northwestern United States (Novy and Vorsa, 1995). This 'Early Black' clone has subsequently been shown not to be the purported cultivar (unpublished data). An additional 12 'McFarlin' samples from Wisconsin and Massachusetts (Table 2) were included to aid in the identification of a consensus RAPD profile. The 10 Massachusetts 'McFarlin' samples were obtained and phenotypically typed by F.

Table 2. Additional 'McFarlin' clones used in the identification of a 'McFarlin' consensus RAPD profile.

\begin{tabular}{lccc}
\hline \hline Clone & I.D. & Source & \multicolumn{1}{c}{ Comments } \\
\hline Bain-1 & US92-6-1 & Wisconsin & 'McFarlin' accessions from Novy and Vorsa (1995) \\
Rezin-1 & US92-9-2 & Wisconsin & Selected by H.F. Bain (U.S. Dept. Agr. pathologist)_Considered to be true 'McFarlin'. \\
Ore. & US89-6 & Oregon & Selection from commercial planting; RAPD profile identical to Bain 'McFarlin'. \\
Wash. \#1 & US93-89 & Washington & Source: U.S. Dept. Agr. Clonal Repository, Corvallis, Ore. \\
Wash. \#2 & US93-93 & Washington & Source: Bog \#1 of this study. \\
N.J. & US94-7 & New Jersey & Source: Bog \#4 of this study. \\
Early Black & US92-55 & Massachusettes & Source: Rutgers experimental bog; Actually the cultivar 'Howes' based on its RAPD profile \\
& & RAPD profile identical to those of Wash.\#1 and Ore. 'McFarlin'-Not a true 'Early Black'. \\
Bain-2 & US88-59 & Wisconsin & Source: DuBays Cranberry Co., Portage Co.-Bain-1 was not obtained from this location. \\
Rezin-2 & US88-72 & Wisconsin & Source: DuBays Cranberry Co., Portage Co.-Same source as Rezin-1. \\
Carver & US93-233, & & Source: commercial bog in Carver, Mass. \\
Wareham & US93-238 & Massachusettes & Source: commercial bog in Wareham, Mass. \\
\end{tabular}


Table 3. Bog means (1993 and 1994) for productivity and berry characteristics of 12 Washington ‘McFarlin’ bogs described in Table 1.

\begin{tabular}{|c|c|c|c|c|c|c|c|c|c|c|c|c|c|c|}
\hline \multirow[b]{2}{*}{$\mathrm{Bog}^{2}$} & \multicolumn{2}{|c|}{$\begin{array}{l}\text { Yield } \\
\mathrm{g} \cdot \mathrm{dm}^{-2}\end{array}$} & \multicolumn{2}{|c|}{$\begin{array}{c}\text { Berry no. } \\
\text { no. } / \mathrm{dm}^{2}\end{array}$} & \multicolumn{2}{|c|}{$\begin{array}{c}\text { Seeds/ } \\
\text { berry }\end{array}$} & \multicolumn{2}{|c|}{$\begin{array}{l}\text { Berry } \\
\text { wt (g) }\end{array}$} & \multicolumn{2}{|c|}{$\begin{array}{c}\text { Berry } \\
\text { set }(\%)\end{array}$} & \multicolumn{2}{|c|}{$\begin{array}{c}\text { Flowers/ } \\
\text { upright }\end{array}$} & \multicolumn{2}{|c|}{$\begin{array}{c}\text { Berries/ } \\
\text { upright }\end{array}$} \\
\hline & 1993 & 1994 & 1993 & 1994 & 1993 & 1994 & 1993 & 1994 & 1993 & 1994 & 1993 & 1994 & 1993 & 1994 \\
\hline \multicolumn{15}{|c|}{ Low production bogs ${ }^{y}$} \\
\hline 1 & $9 \mathrm{bc}$ & 10 ef & $13 \mathrm{~cd}$ & $15 \mathrm{~cd}$ & 12 cde & --- & $0.6 \mathrm{~d}$ & $0.6 \mathrm{~d}$ & $23 \mathrm{de}$ & $32 \mathrm{~cd}$ & $3.1 \mathrm{ab}$ & $3.2 \mathrm{bcd}$ & $0.7 \mathrm{bc}$ & $0.9 \mathrm{~d}$ \\
\hline 2 & $4 \mathrm{c}$ & 5 ef & $5 \mathrm{~d}$ & $7 \mathrm{~cd}$ & $8 \mathrm{e}$ & --- & $0.6 \mathrm{~d}$ & $0.7 \mathrm{~d}$ & $11 \mathrm{e}$ & $38 \mathrm{c}$ & $2.8 \mathrm{bc}$ & $2.9 \mathrm{bcd}$ & $0.4 \mathrm{c}$ & $0.8 \mathrm{~d}$ \\
\hline 5 & $3 \mathrm{c}$ & $9 \mathrm{f}$ & $5 \mathrm{~d}$ & $13 \mathrm{~d}$ & 9 de & --- & $0.8 \mathrm{abc}$ & $0.6 \mathrm{~d}$ & $15 \mathrm{e}$ & $28 \mathrm{~d}$ & $2.8 \mathrm{bc}$ & $2.8 \mathrm{~cd}$ & $0.4 \mathrm{c}$ & $1.1 \mathrm{~d}$ \\
\hline 9 & $5 \mathrm{c}$ & $6 \mathrm{f}$ & $6 \mathrm{~cd}$ & $7 \mathrm{~d}$ & $19 a b$ & --- & $0.9 \mathrm{ab}$ & $1.0 \mathrm{~b}$ & $73 \mathrm{a}$ & $58 \mathrm{~b}$ & $2.4 \mathrm{c}$ & $3.4 \mathrm{ab}$ & $1.7 \mathrm{a}$ & $1.9 \mathrm{bc}$ \\
\hline \multicolumn{15}{|c|}{ Moderate production bogs $s^{y}$} \\
\hline 10 & $6 \mathrm{c}$ & $14 \mathrm{de}$ & $8 \mathrm{~d}$ & $16 \mathrm{c}$ & $21 \mathrm{a}$ & --- & $0.7 \mathrm{bcd}$ & $0.9 \mathrm{bcd}$ & $45 \mathrm{c}$ & $58 \mathrm{~b}$ & $2.4 \mathrm{c}$ & $3.0 \mathrm{a}$ & $1.0 \mathrm{~b}$ & $1.6 \mathrm{c}$ \\
\hline 11 & $12 \mathrm{bc}$ & $22 \mathrm{c}$ & $17 \mathrm{c}$ & $27 \mathrm{~b}$ & $18 a b$ & --- & $0.7 \mathrm{~cd}$ & $0.8 \mathrm{bcd}$ & $58 \mathrm{bc}$ & $61 \mathrm{~b}$ & $3.0 \mathrm{ab}$ & $3.2 \mathrm{~d}$ & $1.7 \mathrm{a}$ & $1.8 \mathrm{bc}$ \\
\hline \multicolumn{15}{|c|}{ High production bogs $s^{y}$} \\
\hline 3 & $35 \mathrm{a}$ & $19 \mathrm{~cd}$ & $38 \mathrm{a}$ & $20 \mathrm{c}$ & $16 a b c$ & --- & $0.9 \mathrm{a}$ & $1.0 \mathrm{bc}$ & $56 \mathrm{bc}$ & $59 \mathrm{~b}$ & $3.5 \mathrm{a}$ & $3.5 \mathrm{ab}$ & $1.8 \mathrm{a}$ & $2.0 \mathrm{bc}$ \\
\hline 4 & $28 \mathrm{a}$ & $31 \mathrm{~b}$ & $28 \mathrm{~b}$ & $29 \mathrm{~b}$ & $14 \mathrm{bcd}$ & --- & $1.0 \mathrm{a}$ & $1.1 \mathrm{ab}$ & $56 \mathrm{bc}$ & $59 \mathrm{~b}$ & $3.2 \mathrm{ab}$ & $3.4 \mathrm{ab}$ & $1.7 \mathrm{a}$ & $2.0 \mathrm{bc}$ \\
\hline 6 & $11 \mathrm{bc}$ & $30 \mathrm{~b}$ & $15 \mathrm{~cd}$ & $41 \mathrm{a}$ & $11 \mathrm{cde}$ & --- & $0.7 \mathrm{bcd}$ & $0.7 \mathrm{~cd}$ & $33 \mathrm{~d}$ & $70 \mathrm{ab}$ & $3.0 \mathrm{ab}$ & $3.9 \mathrm{~cd}$ & $1.0 \mathrm{a}$ & $2.6 \mathrm{a}$ \\
\hline 7 & $37 \mathrm{a}$ & $29 \mathrm{~b}$ & $36 \mathrm{ab}$ & $29 \mathrm{~b}$ & $11 \mathrm{cde}$ & --- & $1.0 \mathrm{a}$ & $1.0 \mathrm{bc}$ & $53 \mathrm{bc}$ & $58 \mathrm{~b}$ & $3.4 \mathrm{ab}$ & $3.4 \mathrm{a}$ & $1.7 \mathrm{a}$ & $1.9 \mathrm{bc}$ \\
\hline 8 & $16 \mathrm{~b}$ & --- & $19 \mathrm{c}$ & --- & $12 \mathrm{cde}$ & --- & $0.9 \mathrm{ab}$ & --- & $62 \mathrm{ab}$ & --- & $3.1 \mathrm{ab}$ & --- & $1.9 \mathrm{a}$ & --- \\
\hline 12 & $28 \mathrm{a}$ & $41 \mathrm{a}$ & $31 \mathrm{ab}$ & $33 \mathrm{~b}$ & $16 a b c$ & --- & $0.9 \mathrm{ab}$ & $1.3 \mathrm{a}$ & $63 a b$ & $78 \mathrm{a}$ & $3.1 \mathrm{ab}$ & $2.8 \mathrm{~d}$ & $1.8 \mathrm{a}$ & $2.1 \mathrm{~b}$ \\
\hline LSD & 7 & 6 & 7 & 6 & 8 & & 0.2 & 0.4 & 9 & 8 & 0.4 & 0.4 & 0.3 & 0.3 \\
\hline
\end{tabular}

${ }^{\mathrm{z}}$ Mean separation within columns by SNK multiple F test $(P \leq 0.05)$.

y Based on grower observation.

Caruso and I. Demoranville of the Massachusetts Cranberry Research Center, East Wareham, Mass., and therefore do not represent a random sampling from their source bogs.

DNA extraction. DNA was extracted from leaf tissue that had been frozen in liquid nitrogen and stored at $-75 \mathrm{C}$ using the minipreparation procedure described by Stewart and Via (1993) with modifications as described by Novy and Vorsa (1995).

DNA amplification and scoring, and analysis of RAPD markers. DNA amplification, electrophoresis, silver staining, band scoring, and analysis were as described in Novy et al. (1994). The primary RAPD analysis was conducted with 8 decamer primers-OPA- 9,11 , 12, 14, and 17 (Operon Technologies, Alameda, Calif.) and U.B.C. 402, 471, and 472 (Univ. of British Columbia Biotechnology Laboratory, Vancouver, Canada). These primers were a subset of those used previously by Novy et al. (1994) and had been shown to provide informative and reproducible RAPD markers among DNA extractions and amplifications. The secondary study used primers OPA-9, OPA-11, and OPA-12. To avoid bias during band scoring, clones were randomized prior to their placement in the thermocycler, and random ordering was maintained in gel loading.

Greenhouse fruiting study. Of the 67 Washington 'McFarlin' uprights that were profiled using RAPD markers in the primary and secondary RAPD analyses, 58 flowered. They were evaluated for fruit set (berries/flowers pollinated), mean fruit weight, mean seed set, and pollen viability. Pollen viability was determined by evaluating the aceto-carmine staining of 200 pollen grains from each upright as described by Ortiz et al. (1992). Pollen grains that were fully stained without shriveling were classified as viable.

ANOVA, multivariate analysis of variance (MANOVA), and correlation analysis were performed using PC-SAS 6.1, (SAS Inst.) Since no preconceived contrasts were employed, mean separation was based on Student-Newman-Keuls test $(P \leq 0.05)$.

\section{Results and Discussion}

Characterization of yield and fruiting habits of 'McFarlin' bogs. All seven yield and fruiting characteristics varied significantly among the bogs sampled in both years (Table 3). Estimated yields, based on sampling, were generally consistent with historical observations. High production bogs ranged from 10.8 to 41.0 $\mathrm{g} \cdot \mathrm{dm}^{-2}$, whereas low production bogs ranged from 3.3 to $9.5 \mathrm{~g} \cdot \mathrm{dm}^{-}$ ${ }^{2}$. Low production bogs exhibited reduced berry number and berry weight. Berry set and berries/upright were also reduced, with the exception of Bog 9.

In 1993, high production Bog 6 exhibited relatively low productivity $\left(10.8 \mathrm{~g} \cdot \mathrm{dm}^{-2}\right)$ as a result of frost damage prior to bloom. The following year, the productivity of Bog $6\left(29.6 \mathrm{~g} \cdot \mathrm{dm}^{-2}\right)$ was consistent with the high productivity classification. Bog 8 , classified as a high production bog based on grower observation, is more consistent as a moderate production bog based on observed yield and fruiting characteristics (Table 3).

Except for Bog 9, the low production bogs are characterized by lower yields, low berry number, smaller fruit, and reduced fruit set, seed number, and berries/upright. Although Bog 9 is classified as a low production bog, it appears to be distinct from the other three low production bogs based on significantly greater fruit weight, seed number, fruit set, and fruit/upright (Table 3 ).

The high production bogs are characterized by relatively high yields, berry number, fruit weight ( $>1 \mathrm{~g}$ ), fruit set over $50 \%$, over 3 flowers/upright, and about two fruit/upright (Table 3).

$R A P D$ analyses. Variable band profiles were obtained with the first primer, OPA-11, indicating that more than one genotype was present in the 45 'McFarlin' uprights. Seven additional primers were used in the study to assess the genetic relationships among the uprights. 85 scorable DNA fragments were identified, of which 45 (53\%) were polymorphic among the 'McFarlin' clones. The genetic distance values (tallies of band differences between clones) calculated from these 45 RAPD markers ranged from 0-30, with a mean distance of 17 and a median distance of 12 . The dendrogram generated from the genetic distance values (Fig. 1) shows the 45 uprights to be represented by 15 RAPD profiles. The RAPD profiles can be separated into eight groups, when profiles having less than the median value of 12 are assigned to a group (Fig. 1). Groups E, F, G, and $\mathrm{H}$ are represented by a single RAPD profile. Profile 10 was identical to that of cultivar 'Howes' in a previous study (Novy and Vorsa, 1995). 
Fig. 1. Average-linkage dendrogram of relatedness among 45 clonal samples of 'McFarlin' cranberry. Units of distance were derived from the number of RAPD differences among the clones. Fifteen unique RAPD profiles were identified and numbered. Profile 15 is classified as true 'McFarlin'. The values in parentheses refer to the number of analyzed clones having that RAPD profile. RAPD profiles that differed by less than the median of 12 band differences separated into eight groups $(\mathrm{A}-\mathrm{H})$. A cophenetic correlation value of $r=0.95$ indicates there is a very high level of agreement between the dendrogram and the original dissimilarity matrix.

The combined results of both the primary and secondary RAPD analyses (Table 4) indicate a high degree of genetic heterogeneity within the bogs. Nine of the twelve bogs had more than one RAPD profile represented. As expected in an asexually propagated crop, numerous uprights were found to have identical RAPD profiles, indicating they are identical or closely related genotypes. RAPD profiles $3,6,7,8,9$, and 11 were unique to the Long Beach samples, while profiles $2,4,12,13$, and 14 were specific to the Grayland samples. RAPD profiles $1,5,10$, and 15 were common to both growing regions.

RAPD profiles $1,2,4$, and 5 were associated with the low production bogs 1,2 , and 5 (Table 4 ). With the exception of profile

Table 4. Genetic composition of 67 clonal samples obtained from Washington State 'McFarlin' bogs.

\begin{tabular}{|c|c|c|c|c|}
\hline \multirow[b]{2}{*}{$\operatorname{Bog}^{x}$} & \multicolumn{2}{|c|}{ Primary RAPD analysis $^{z}$} & \multicolumn{2}{|c|}{ Secondary RAPD analysis ${ }^{y}$} \\
\hline & $\begin{array}{c}\text { No. of } \\
\text { samples }\end{array}$ & $\begin{array}{c}\text { RAPD profiles } \\
\text { observed }^{\mathrm{w}}\end{array}$ & $\begin{array}{c}\text { No. of } \\
\text { samples }\end{array}$ & $\begin{array}{c}\text { RAPD profiles } \\
\text { observed }\end{array}$ \\
\hline$\overline{1}$ & 3 & $1,1,4$ & 3 & $1,1,1$ \\
\hline 2 & 4 & $2,2,2,10$ & --- & --- \\
\hline 3 & 3 & $13,15,15$ & 5 & $15,15,15,15,15$ \\
\hline 4 & 4 & $14,14,15,15$ & 1 & 15 \\
\hline 5 & 4 & $1,1,2,5$ & 3 & $1,1,1$ \\
\hline 6 & 4 & $15,15,15,15$ & 1 & 15 \\
\hline 7 & 4 & $15,15,15,15$ & --- & --- \\
\hline 8 & 4 & $10,10,12,14$ & 2 & 10,10 \\
\hline 9 & 3 & $6,6,6$ & 1 & 6 \\
\hline 10 & 4 & $3,8,10,11$ & 1 & 1 \\
\hline 11 & 4 & $10,10,10,15$ & 4 & $10,10,10,10$ \\
\hline 12 & 4 & $7,9,9,10$ & 1 & 5 \\
\hline
\end{tabular}

${ }^{\mathrm{z}}$ Analysis performed with eight primers.

${ }^{\mathrm{y}}$ Analysis performed with a subset of three primers.

${ }^{\mathrm{x}}$ Bog numbers correspond to those in Table 1 .

wRAPD profile values correspond to Fig. 1 designations.
5, they were unique to these three bogs (Table 4). Being members of the same group (A), they would appear to be related (Fig. 1). RAPD profile 6 was found for all samples from bog 9, another low producing bog.

RAPD profile 15 predominated in four of the six high-production bogs (bogs 3, 4, 6, and 7), but was not found in any of the samples (21 uprights) from the four low production bogs (yields $<10 \mathrm{t} / \mathrm{ha}$ ). The abundance of RAPD profile 15 in high production bogs suggests it may represent the true 'McFarlin'.

Other RAPD profiles, however, were also found in high production bogs. Two high-production bogs (bog 8 and 12) did not have profile 15 represented. Although initially classified as a high production bog, the yield of bog 8 in 1993 was more similar to that of moderate-producing bogs (Table 3 ). Bog 8 and bog 11, having a high frequency of profile 10 (Table 4 ), would be better classified as 'Howes' bogs.

Although productive, bog 12 did not have RAPD profile 15 represented (Table 4 ). To ascertain whether profile 15 would be found in a larger sample, 19 additional uprights from bog 12 were analyzed with primers OPA-11 and OPA-12. 10 of 19 uprights had RAPD profiles identical to RAPD profile 9, and appears to be the most abundant (44\%) profile within bog 12 . 'McFarlin' profile 15 was lacking. Therefore, profile 9 possibly represents another high yielding-genotype, apparently unrelated to RAPD profile 15.

RAPD profiles of additional samples of 'McFarlin' from Washington, Oregon, Wisconsin, Massachusetts, and New Jersey (Table 2), when analyzed with the Washington samples, yielded the same dendrogram as seen in Fig. 1. No new RAPD profiles were identified among the additional 19 'McFarlin' samples, suggesting the genotypes in Washington bogs were of Eastern origin.

Washington \#1, 'Early Black', and Oregon 'McFarlin' were represented by RAPD profile 5, a profile associated with low production. Noteworthy was the finding that Oregon 'McFarlin' (obtained from the U.S. Dept. Agr. Natl. Clonal Germplasm Repository) also had this RAPD profile. This clonal accession was originally collected from a bog in North Bend, Ore., indicating that this putative lower-yielding 'McFarlin' genotype is not limited to Washington bogs. The identification of an 'Early Black' clone with an identical RAPD profile to this class of 'McFarlin' clones demonstrates the confusion regarding genotype and cultivar classification in cranberry. Washington \#2, an additional 'McFarlin' clone from bog 4, was represented by RAPD profile 14. This profile had been previously identified in 2 of 4 samples from that bog. New Jersey 'McFarlin' was identified as the cultivar 'Howes' (Novy and Vorsa, 1995), and was considered the only incident of a 'Howes' being misclassified as a 'McFarlin'. However, this 'Howes' clone had a RAPD profile (10) identical to eight other Washington 'McFarlin' uprights in the primary RAPD analysis (Fig. 1).

Based on abundance in higher-yielding bogs and presence across bogs in the study, RAPD profile 15 is hypothesized to be the original or true 'McFarlin'. With the exception of Bain-2, the 'McFarlin' samples from Massachusetts and Wisconsin also exhibited RAPD profile 15.

Greenhouse experiment. The 58 uprights were assigned to one of the eight groups (Fig. 1). Since groups A, B, C, D, and H were represented by more than one upright, an estimate of within group variance was possible. Group means for all four measured variables varied significantly (Table 5). Of the 10 pairwise group contrasts possible among these five groups, only the $\mathrm{C}$ vs. $\mathrm{H}$ contrast did not differ significantly for any variable. However, all four measured variables were significantly correlated to at least one other variable within the group (Table 6). MANOVA provided 
Table 5. Upright group (based on RAPD profile) means of measured and derived Z variables (MANOVA) from greenhouse fruiting study.

\begin{tabular}{|c|c|c|c|c|c|c|c|c|}
\hline Group $^{z}$ & $\mathrm{~N}$ & $\begin{array}{c}\text { Mean } \\
\text { fruit } \\
\text { wt } \\
\text { (MFWT) }\end{array}$ & $\begin{array}{l}\text { Mean } \\
\text { seed/ } \\
\text { berry } \\
\text { (MSD) }\end{array}$ & $\begin{array}{c}\text { Fruit } \\
\text { set } \\
(\mathrm{FS})\end{array}$ & $\begin{array}{c}\text { Pollen } \\
\text { stainability } \\
(\%) \\
\text { (PS) }\end{array}$ & $\mathrm{Z} 1^{\mathrm{y}}$ & $\mathrm{Z} 2^{\mathrm{y}}$ & $\mathrm{Z}^{\mathrm{y}}$ \\
\hline$\overline{\mathrm{A}}$ & 14 & $0.6 b$ & $3.7 \mathrm{c}$ & $38.7 b$ & $66.3 b$ & $0.8 \mathrm{~b}$ & $-0.16 b$ & $-0.23 a b$ \\
\hline B & 3 & $0.6 \mathrm{~b}$ & $4.7 \mathrm{c}$ & $50.0 \mathrm{ab}$ & $95.6 \mathrm{a}$ & $1.2 \mathrm{a}$ & $-0.31 \mathrm{c}$ & $-0.30 b$ \\
\hline $\mathrm{C}$ & 8 & $1.6 \mathrm{a}$ & $14.5 \mathrm{a}$ & $77.1 \mathrm{a}$ & $92.7 \mathrm{a}$ & $1.2 \mathrm{a}$ & $-0.01 \mathrm{a}$ & $-0.08 \mathrm{a}$ \\
\hline D & 14 & $1.5 \mathrm{a}$ & $7.4 \mathrm{bc}$ & $78.0 \mathrm{a}$ & $56.5 b$ & $0.7 b$ & $0.13 a$ & $-0.18 \mathrm{ab}$ \\
\hline $\mathrm{E}^{\mathrm{x}}$ & 1 & 2.0 & 10.0 & 33.3 & 80.3 & 1.1 & 0.16 & -0.30 \\
\hline $\mathrm{F}^{\mathrm{x}}$ & 1 & 1.3 & 14.0 & 33.3 & 89.6 & 1.3 & -0.05 & -0.08 \\
\hline $\mathrm{G}^{\mathrm{x}}$ & 1 & 1.4 & 18.0 & 33.3 & 90.1 & 1.3 & -0.03 & 0.06 \\
\hline $\mathrm{H}$ & 14 & $2.0 \mathrm{a}$ & $10.9 \mathrm{ab}$ & $74.6 \mathrm{a}$ & $90.0 \mathrm{a}$ & $1.2 \mathrm{a}$ & $0.12 \mathrm{a}$ & $-0.29 b$ \\
\hline
\end{tabular}

\footnotetext{
${ }^{\mathrm{z}}$ Mean separation within columns by SNK multiple F test $(P \leq 0.05)$.

'Derived variables, $\mathrm{Z} 1=0.050(\mathrm{MFWT})+0.013(\mathrm{MSD})-0.003(\mathrm{FS})+0.012(\mathrm{PS}) ; \mathrm{Z} 2=0.273(\mathrm{MFWT})$

$+0.002(\mathrm{MSD})-0.002(\mathrm{FS})-0.005(\mathrm{PS}) ; \mathrm{Z3}=-0.181(\mathrm{MFWT})+0.037(\mathrm{MSD})+0.001(\mathrm{FS})-0.004(\mathrm{PS})$.

${ }^{\mathrm{x}}$ Groups having only one observation were not included in ANOVA.
}

four uncorrelated derived characteristic vectors $(\mathrm{Z} 1, \mathrm{Z2}, \mathrm{Z3}$, and Z4), which are linear derivatives of the four measured variables. The first three vectors were significantly variable (not given), accounting for $65.8 \%, 23.8 \%$, and $7.5 \%$ of the variation, respectively. Z1, Z2, and Z3 characteristic group means varied significantly (Table 5). All five groups differed significantly from one another for at least one vector, indicating at least five distinct phenotypes. Except for Group C vs. Group H contrast, which is differentiated by the $\mathrm{Z} 3$ characteristic, the remaining contrasts can be seen in Fig. 2. Of the 14 Group D uprights, 13 having RAPD profile 10 grouped at $Z 10.8$, while the one upright having RAPD profile 11 was located at $Z \leq 1.1$ (Fig. 2).

Group A representatives, originating largely from the three low production bogs, exhibited significantly reduced fruit weight, seed number, fruit set, and pollen stainability (Table 5), indicating this genotype is less fertile. Group B representatives also originated from two of these bogs (bogs 1 and 5), and except for pollen stainability exhibited reduced female fertility. Group C RAPD profiles originated from bogs of considerable variability in production. Group C RAPD profile 6 representatives all came from bog 9, a low production bog, while RAPD profile 9 appears to predominate in the high production bog 12 . However, all Group C uprights appear to have characteristics associated with high production, similar to group H (RAPD profile 15) with significantly greater fruit weight, fruit set, and pollen stainability than group A (Fig. 2 and Table 5). Group D composed largely of 'Howes' RAPD profile 10 had relatively good female fertility, but reduced pollen stainability (Table 5). Groups E, F, and G (RAPD profiles 12, 13, and 14) were found only in Grayland bogs and appear similar in fertility to groups $\mathrm{C}$ and $\mathrm{H}$ (Fig. 2). Group H (RAPD profile 15), identified as the true 'McFarlin', uprights exhibited relatively high female and pollen fertility.

Washington 'McFarlin' bogs are composed of a diverse array of genotypes with variable fruiting phenotypes. Identical RAPD

Table 6. Correlation coefficients for fruit variables measured.

\begin{tabular}{|c|c|c|c|c|}
\hline & $\begin{array}{l}\text { Mean } \\
\text { fruit wt }\end{array}$ & $\begin{array}{c}\text { Mean } \\
\text { seed/berry }\end{array}$ & $\begin{array}{c}\text { Fruit } \\
\text { set }(\%)\end{array}$ & $\begin{array}{c}\text { Pollen } \\
\text { stainability }(\%)\end{array}$ \\
\hline$\overline{\text { Mean fruit wt }}$ & --- & $0.49^{* * * *}$ & $0.57^{* * * *}$ & $0.26^{\mathrm{ns}}$ \\
\hline Mean seed/berry & & --- & $0.38^{* *}$ & $0.19^{\mathrm{ns}}$ \\
\hline Fruit set (\%) & & & --- & $0.41^{* * *}$ \\
\hline
\end{tabular}

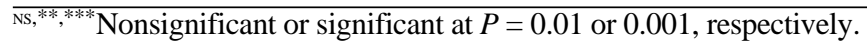

profiles found among Eastern (Massachusetts, Wisconsin, New Jersey) and Washington variants, and the lack of native $V$. macrocarpon in the Pacific Northwest suggests that 'McFarlin' propagules brought west were genotypically heterogeneous.

The variants may have already constituted a major portion of the Eastern bogs, and were then propagated in Washington bogs. Alternatively, these variants may have comprised a small proportion of initial propagations but eventually outcompeted or were better adapted than the 'McFarlin' genotype in the Washington environment. Partitioning fewer resources to sexual reproduction, less fertile genotypes would allow for greater partitioning to vegetative reproduction. Another RAPD profile (6) originating from a low production bog exhibited fruit characteristics similar to 'McFarlin', having larger fruit size, higher seed number, and fruit set. The low productivity would appear to be the result of other genetic, e.g., reduced vigor or environmental factors. Interestingly, another genotype, RAPD profile 9, assigned to the same RAPD group may be a high yielding genotype.

The presence of the cultivar 'Howes' in 'McFarlin' bogs provides evidence for varietal misclassification as yet another source of genetic variation. Records indicate that while 'McFarlin'

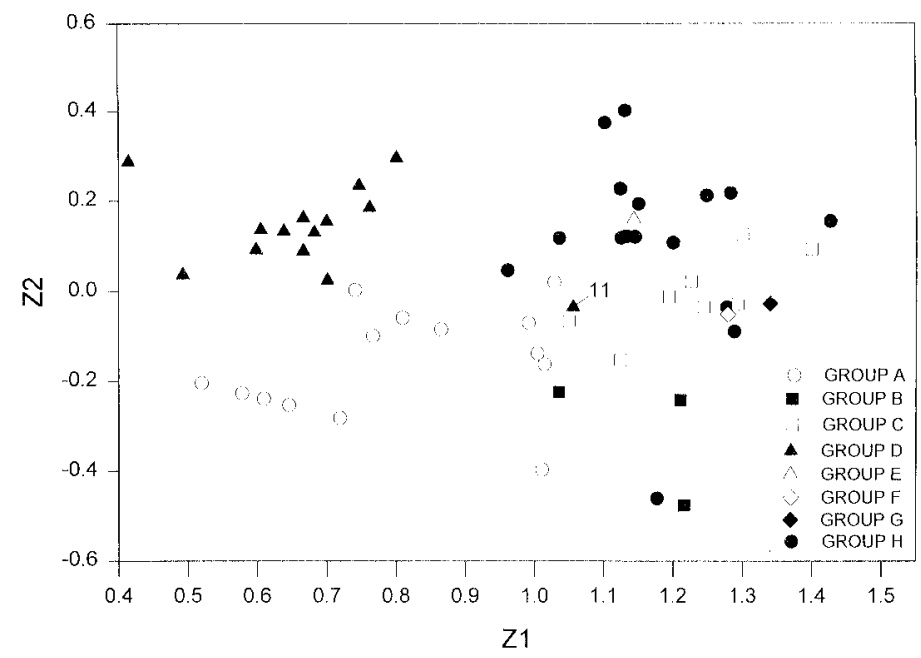

Fig. 2. First two $Z$ vectors from MANOVA analysis of fruiting characteristics of uprights in greenhouse study. $Z$ vectors derived from four characteristics: fruit set, mean berry weight, mean seeds/berry, and pollen stainability. Group D upright at $\mathrm{Z} 1=1.1$ and $\mathrm{Z} 2=-0.08$ is $\mathrm{RAPD}$ profile 11 . 
was the primary cultivar used in establishing the first cranberry bogs in Grayland (and most likely Long Beach), smaller acreages were also planted with 'Howes' (O'Brien, 1936). Apparently, over the fifty to sixty years since these bogs were established, at some point they were misclassified as 'McFarlin' bogs.

With the exception of four RAPD profiles, the remaining genotypes identified were common to only one of the growing areas, suggesting that the initial sources of propagules for the establishment of bogs were of different origin. In addition, the wide disparity in relatedness among the Grayland clones would suggest more than one source of propagules for this area.

Most bogs in this study were represented by more than one RAPD profile, suggesting that most bogs are genetically heterogeneous populations. Thus, if environmental changes occur, artificial or natural, changes in the genotypic composition may be expected over time.

A RAPD profile (15) was identified to represent the true 'McFarlin'. Besides having fruiting characteristics associated with greater yield potential, this RAPD profile also represented 'McFarlin' accessions from Wisconsin and Massachusetts. The larger fruit size and greater fruit set of this profile is consistent with observed bog characteristics.

Using the same eight primers of the primary RAPD analysis, RAPD profile 15 differed by only 11 bands from 'Stevens', a hybrid progeny of 'McFarlin' (unpublished data). An average of a 22-band difference was observed between profile 15 and the other 14 RAPD profiles in this study, suggesting that they are not selfed or hybrid progeny of 'McFarlin'.
Combining phenotypic observation and RAPD analysis has proven useful in the identification of true 'McFarlin', and another high-yielding unrelated genotype. This study has also shown the wide range of genetic variability that exists in Washington 'McFarlin' bogs, which apparently is not unique to the 'McFarlin' cultivar or Washington (Novy and Vorsa, 1995). RAPD analysis, together with analysis of plant characteristics, can be useful in the identification of true cultivars and other high-yielding cranberry genotypes.

\section{Literature Cited}

Eck, P. 1990. The American cranberry. Rutgers Univ. Press, New Brunswick, N. J.

Novy, R.G., C. Kobak, J. Goffreda, and N. Vorsa. 1994. RAPDs identify varietal misclassification and regional divergence in cranberry ( $\mathrm{Vac}$ cinium macrocarpon Ait.). Theor. Appl. Genet. 88:1004-1010.

Novy, R.G. and N. Vorsa. 1995. Identification of intracultivar genetic heterogeneity in cranberry using silver-stained RAPDs. HortScience 30:600-604.

O'Brien, J., 1936. A few notes from the Grayland district in Washington state. Cranberries (May)

Ortiz, R., N. Vorsa, L.P. Bruederle, and T. Laverty. 1992. Occurrence of unreduced pollen in diploid blueberry species, Vaccinium sect. Cyanococcus. Theor. Appl. Genet. 85:55-60.

Sarracino, J.M. and N. Vorsa. 1991. Self and cross fertility in cranberry. Euphytica 58:129-136.

Stewart, C.N., Jr. and L.E. Via. 1993. A rapid CTAB DNA isolation technique useful for RAPD fingerprinting and other PCR applications. BioTechniques 14(5):748-750. 